\title{
APPELLATE REVIEW OF DETERMINATIONS OF PATENTABLE INVENTIONS
}

The question whether patent validity is an issue of law or an issue of fact has been one of the most troublesome problems in the patent field. The case law in this area consists of numerous conflicting decisions 1 and a considerable amount of inconsistent reasoning. Since the scope of appellate review of patent validity is determined by the resolution of this problem, ${ }^{2}$ an attempt to achieve some uniformity is desirable.

Patent validity is determined by the satisfaction of the statutory requirements ${ }^{3}$ of the Patent Act. 4 There is no doubt that the overall question of validity is a legal one, 5 but a problem arises in relation to the criteria which determine validity-novelty, utility, and invention. 6 It has generally been

1 In the Seventh Circuit, for example, the court held that validity was a question of law in Harley C. Loney Co. v. Ravenscroft, 162 F.2d 703, 704 (7th Cir. 1947); a question of fact in Hazeltine Research, Inc. v. Admiral Corp., 183 F.2d 953, 954-55 (7th Cir. 1950); and again a question of law in Noble Co. v. C. S. Johnson Co., 241 F.2d 469, 476 (7th Cir. 1957 ). Similarly in the Ninth Circuit the court in Kwikset Locks, Inc. v. Hillgren, 210 F.2d 483, 488 (9th Cir. 1954), rejected a suggestion that "a finding of validity is a finding of fact"; in Stauffer v. Slenderella Systems of Cal., Inc., 254 F.2d 127 (9th Cir. 1957), it stated: "This court has consistently held that the question of validity ... is one of fact"; but a month later in Bergman v. Aluminum Lock Shingle Corp. of America, 251 F.2d 801. 803 (9th Cir. 1957) the court quoted with approval: "[T] "The question of validity of a patent is a question of law." "

${ }^{2}$ It has been suggested that appellate courts sometimes review the trial court's determination with respect to patent validity independently of the law-fact problem. $C f$. Hanovia Chem. \& Mfg. Co.v. David Buttrick Co., 127 F.2d 888 (1st Cir. 1942), where the court noted that if the question is one of fact the findings should not be set aside in the absence of clear error. But the court pointed out that "in spite of this the fact remains that there are in the reports a great number of cases in which federal appellate courts have themselves ... decided the question of patentable invention without according any weight whatever to the conclusion thereon reached below." Id. at 889 . Nevertheless, most courts have continued to approach the problem from the standpoint of the law-fact analysis. $C f$. Armour \& Co. v. Wilson \& Co., 274 F.2d 143 (7th Cir. 1960). This paper will, therefore, deal with the issue in those terms.

${ }^{3}$ It is also necessary that the patent satisfy the constitutional requirements of U.S. Const. art. I, $\$ 8$. Since this is obviously a legal question, an appellate court may review at least to the extent of determining whether the constitutional purpose of promoting "science and the useful arts" has been fulfilled.

4The statute provides: "Whoever invents or discovers any new and useful process, machine, manufacture, or composition of matter, or any new and useful improvement thereof, may obtain a patent therefor, subject to the conditions and requirements of this title." 35 U.S.C. \$101 (1958).

5 The meaning of the statute is, of course, a question of law, but if it is a question of fact whether each requirement has been satisfied, the legal issue will depend entirely upon findings of fact.

6 Other requirements for patentability, such as the filing of an application, are not relevant to this study. 
accepted that novelty 7 and utility 8 are issues of fact, but invention 9 has at various times been held to be a legal, ${ }^{10}$ factual11 or mixed 12 question. It is with this latter requirement of invention that any useful analysis of the lawfact problem regarding patent validity must deal.

In early patent cases the Supreme Court consistently appeared to take the position that invention was a question of fact. In Keyes $v$. Grant 13 the Court wrote: "It was insisted by the patentee that ... the improvement which ... . [the device] constituted was not the result of mere mechanical skill, but sprang from a genuine effort of invention. ... In our opinion this was a question of fact properly to be left for determination to the jury. ..."14 Substantially the same rule has been followed in other cases ${ }^{15}$ with one exception. 16

7 In Graver Tank \& Mfg. Co. v. Linde Air Prod. Co., 339 U.S. 605, 609 (1950) the Court held that "a finding of equivalence is a determination of fact." Accord, Bischoff v. Wethered, 76 U.S. (9 Wall.) 812,814 (1869); Turrill v. The Michigan, S. \& C. R.R. Co., 68 U.S. (1 Wall.) 491, 512 (1863).

8 Harley C. Loney Co. v. Ravenscroft, 162 F.2d 703, 704 (7th Cir. 1947); Gordon Form Lathe Co. v. Ford Motor Co., 133 F.2d 487, 496 (6th Cir. 1943).

9 The classic test for invention is whether the patented device was the result of more than "ordinary" or "mechanical" skill. If not, invention is absent. This test is now embodied in the Patent Act. It is provided that no patent will be issued if "the differences between the subject sought to be patented and the prior art are such that the subject matter as a whole would have been obvious at the time the invention was made to a person having ordinary skill in the art to which said subject matter pertains." 35 U.S.C. $\$ 103$ (1958).

Judge L. Hand has argued that Section 103 of the Patent Act lowered the standard of invention from that which had been applied twenty-five years earlier. His position appears to be that since 1930 the "ordinary skill" test has been applied with greater severity but that $\S 103$ requires that the test be applied as it had been applied as it had been through the 1920's. See Lyon v. Bausch \& Lomb Optical Co., 224 F.2d 530 (2d Cir. 1955). For an opinion by Judge Frank expressing doubt as to Judge Hand's conclusion, see Vermont Structural Slate Co. v. Tatko Bros. Slate Co., 233 F.2d 9, 11 n.3 (2d Cir. 1956). This comment is of course concerned, not with what the standard of invention is, but with who is to determine that standard.

10 Armour \& Co. v. Wilson \& Co., 274 F.2d 143 (7th Cir. 1960); Cee-Bee Chem. Co. v. Delco Chems., Inc., 263 F.2d 150, 153 (9th Cir. 1958).

11 White Cap Co. v. Owens-Illinois Glass Co., 203 F.2d 694, 696 (6th Cir. 1953); Trico Prods. Corp. v. Delman Corp., 180 F.2d 529, 530 (8th Cir. 1950).

12 Hycon Mfg. Co. v. H. Koch \& Sons, 219 F.2d 353, 355 (9th Cir. 1955).

15118 U.S. 25 (1886).

14 Id. at 37.

15 Dow Chem. Co. v. Halliburton Oil Well Cementing Co., 324 U.S. 320 (1945) (dictum); Williams Mfg. Co. v. United Shoe Mach. Corp., 316 U.S. 364 (1942); Thomson Spot Welder Co. v. Ford Motor Co., 265 U.S. 445 (1924) (dictum); Continental Paper Bag Co. v. Eastern Paper Bag Co., 210 U.S. 405 (1908).

${ }^{16}$ Mahn v. Harwood, 112 U.S. 354 (1884), has been generally relied upon as authority for the proposition that invention is a question of law. See Goodyear Tire \& Rubber Co. v. Ray-O-Vac Co., 321 U.S. 275, 280 n.1 (1944) (dissenting opinion); Bergman v. Aluminum Lock Shingle Corp. of America, 251 F.2d 801, 803 (9th Cir. 1957); Note, A Valid Patent -Graver v. Linde, 5 N.Y.U. INTRA. L. REv. 70 (1950). All of the cases upon which the Mahn Court itself relies were actions in equity, holding merely that "findings of invention" 
More recently the view that invention is a question of fact found further support in Graver Tank Mfg. Co. v. Linde Air Prods. Co.17 The patentees claimed the discovery of a new composition and process for use in electric welding. At trial the district court upheld the validity of the composition claims, 18 but not that of the process claims. 19 On appeal all claims were found valid, 20 but on review the Supreme Court reinstated the district court's judgment. Referring to the impact of Rule 52(a)21 on the issue of invention, the Court, through Mr. Justice Jackson, said:

To no type of case is this last clause [regarding the trial judge's evaluation of witness credibility] more appropriately applicable than to the one before us, where the evidence is largely the testimony of experts as to which a trial court may be enlightened by scientific demonstrations....

...

While the ultimate question of patentability is one of meeting the requirements of the statute ... the facts as found ... warrant a conclusion here that as [a] matter of law those statutory requirements have been met. ${ }^{22}$

This opinion has generally been accepted 23 as an unequivocal statement

are within the scope of appellate review. Each of these cases was decided at a time when appellate courts reviewed facts as well as law in equity cases. La Abra Silver Mining Co. v. United States, 175 U.S. 423, 464-65 (1899). Consequently, one can not infer that invention is a question of law from the mere fact that, as stated in the Mahn case, "courts are not bound by the decision of the commissioner." 112 U.S. at 358 .

Furthermore the question in the Mahn case was whether the reissue of a patent for the purpose of enlarging the claim had been properly granted. The Court held only that where a patentee has originally claimed less than he is entitled to claim, "he is bound to discover the defect in reasonable time . . . and if the Commissioner of Patents, after the lapse of such reasonable time, undertakes to grant a reissue for the purpose of correcting the supposed mistake, he exceeds his power, and acts under a mistaken view of the law. ..."112 U.S. at 362 . Thus the statement that invention is a question of law was mere dictum. The patent in the Maln case was invalid, not for lack of invention, but for unreasonable delay in the correction of a defect in the patent claim.

17336 U.S. 271 (1949).

13 It found that the patentees had "discovered what they sought-compositions which when employed in a welding operation . . give a vastly improved weld ... which permit the welding of far thicker plates in a single pass and at a speed many times faster than attained by any prior known method, and which completely eliminate the splatter and blinding glare of the so-called open arc." 75 U.S.P.Q. 231, 234 (N.D. Ind. 1947).

19 The court said that if no "electric arc" were present, the patentee's process would be an invention. "But no such finding can be made. The evidence is persuasive that no such basic difference in phenomena is present in the [patentee's] . . method." Id. at 233.

20167 F.2d 531 (7th Cir. 1948).

21 That rule provides: "Findings of fact shall not be set aside unless clearly erroneous, and due regard shall be given to the opportunity of the trial court to judge of the credibility of the witnesses. ..." FED. R. CIv. P. 52(a).

22336 U.S. 271, 274-75 (1949).

${ }^{23}$ For example, the court in Hazeltine Research, Inc. $\because$. Admiral Corp., 183 F.2d 953, 954-55 (7th Cir. 1950) referred to the Graver case and said: "Thus, there is no room longer to doubt that the issues most prevalent in patent litigation, and particularly those of validity or invalidity, infringement or non-infringement, are issues of fact," 
that invention is an issue of fact. 24 Indeed, the Supreme Court itself indicated only a few months later in Faulkner v. Gibbs, 25 that this was the import of the Graver case. There the Court, in affirming a judgment of patent validity, 26 said: "We will not disturb the concurrent findings upon the issues presented to us in the petition for certiorari. We are not persuaded that the findings are shown to be clearly erroneous." 27

However, in a case subsequent to Faulkner, doubt was cast on the reliability of the traditional notion that invention is an issue of fact. Great Atl. \& Pac. Tea Co. v. Supermarket Equip. Corp. 28 involved a patent issued for a counter with an extension for a three-sided tray with which to pull purchases in front of a supermarket cashier. The district court ${ }^{29}$ had found, and the court of appeals agreed, 30 that this conception was "a decidedly novel feature and constituted a new and useful invention" even though all of the features of the device, except the extension of the counter, were previously known. The Supreme Court reversed the judgment, but expressly refused to

24 Since the Court did not specify what it means by the phrase "the facts as found," one might speculate whether invention is itself one of those facts or whether the term "facts" refers instead to the evidentiary findings, from which invention follows as a conclusion of law. However the latter alternative seems improbable in view of the majority's use of the "two-court rule" under which the Supreme Court refuses to review concurrent findings of fact in the absence of "exceptional showing of error." The Court applied this rule in reply to a suggestion that "we . . . hold that there has been no such invention." 336 U.S. 271, 274 (1949). But if invention were considered a conclusion of law, one would not expect the Court to respond to that suggestion with a rule about findings of fact. Furthermore, the two-court rule was applied only in connection with those claims which both of the lower courts had held to be inventive. Yet there would be no reason for failing to apply the rule if the two courts had merely disagreed as to a legal conclusion.

2s 338 U.S. 267 (1949).

26 The patented device, discussed in Gibbs v. T.Z.R. Amusement Corp., 14 F. Supp. 957 (E.D.N.Y. 1936), was a game consisting of a group of identical boards, each connected to an annunciator which contained lights that turned on automatically when a ball, rolled by a player from the other end of the board, fell into any of the twenty-five holes systematically arranged on the top of the board. A previous patent, granted for a game in which a player rolled three balls which, when they fell into the prize-winning holes in the board, caused the annunciator to illuminate, was distinguished on the grounds that the annunciator light in that device went off if the ball became dislodged from the hole before all prize-winning apertures were occupied.

If, under the Graver rule, invention were a conclusion reached on the basis of the evidentiary facts, one would expect the Court, in stating its conclusion, to show how it is supported by those facts. In the Graver case the Court's failure to indicate the reasoning that led from the findings of fact to its legal conclusion might be explained on the grounds that the inferences followed so clearly and inevitably that no discussion was needed. And this argument would be supported by the fact that two Justices who believed that the twocourt rule and Rule 52(a) were inapplicable to the case nevertheless reached the same con- clusion as to what the patentee had invented. But in the Faulkner case no such rationalization is possible. For there the least that must be conceded is that, given the evidentiary facts, reasonable men might disagree with the Court's conclusion.

27338 U.S. at 268.

28340 U.S. 147 (1950).
2978 F. Supp. 388 (E.D. Mich. 1948).

30179 F.2d 636 (6th Cir. 1950). 
discard the Graver rule. In holding the patent invalid for lack of invention, the Court, again speaking through Mr. Justice Jackson, said:

It is urged, however, that concurrence of two courts below, in holding the patent claims valid, concludes this Court. ... [But] we set aside no finding of fact as to invention, for none has been made except as to the extension of the counter, which cannot stand as a matter of law. The defect that we find ... is that a standard of invention appears to have been used that is less exacting than that required where a combination is made up of entirely old components. 31

Since the Court seemed to believe that it was not reversing a factual finding of invention, it might be thought that the $A \& P$ case leaves the Graver holding intact. 32 But any attempt to reconcile these cases on the basis of that belief in $A \& P$ is foreclosed by the decision in Crest Specialty $v$. Trager. ${ }^{33}$ The Court there, citing only the $A \& P$ case, reversed per curiam a judgment of patent validity, entered by the trial court ${ }^{34}$ and affirmed by the court of appeals. ${ }^{35}$

In $A \& P$ the Supreme Court had stated that the wrong standard of invention had been applied below and that no finding of invention had been made. Neither of these theories would justify the reversal of the concurrent findings in the Trager case, for there the trial court, applying the classic "skilled artisan" test, had expressly found that there had been an invention. ${ }^{36}$ Thus be-

31340 U.S. at 153-54. The opinion of the trial judge, however, shows that he concluded that there had been an invention. The court wrote: "During the trial of this case and after examining all previous patents deemed as being at all similar to the patent before us ... we indicated that we could see no similarity between any of these patents and the one at bar. We are still of this opinion." $78 \mathrm{~F}$. Supp. at 393. In addition the court indicated that the patentee had had a "flash of creative genius." Ibid.

Furthermore, the Supreme Court appears to have misunderstood the findings below, for the trial judge said, not that the extension was the only inventive element of the combination, but that it was the only novel element. After pointing out that certain parts of the combination were old, the court stated: "However, the extension of the checking-out counter was apparently something new. ..."78 F. Supp. at 391.

32 One writer has placed the blame for the confusion that has developed at the doors of the district court which tried $A \& P$ and the court of appeals which received its judgment. "In view of the errors of law and ambiguous findings of the courts below, it cannot be said that the $A . \& P$. case is out of line with the Graver case." Note, Appellate Review of Findings of Invention, 20 GEO. WASH. L. REV. 605, 611 (1952).

33341 U.S. 912 (1951).

3489 F. Supp. 199 (N.D. Ill. 1950).

35184 F.2d 577 (7th Cir. 1950).

${ }^{36}$ The subject matter consisted of a simulated animal perched on the rim of an infant's feeding bowl. The animal's mouth opened and food which was inserted into it passed through the animal's hollow body and back into the child's bowl. The defendant argued that the patent had been anticipated by a device consisting of a cereal bowl with a hopper positioned inside of it so as to separate the milk and cereal. The trial court held: "The conception and production of a device like that ... in suit was beyond the skill of a mechanic, and required the exercise of inventive genius. . . . [The patent] is . . . good and valid in law." 89 F. Supp. at 204. 
cause the $A \& P$ case appears to hold that the Supreme Court may review a determination of invention, the indication is that the Court considered invention a question of law. 37

The conflict between Graver and $A \& P$, although not apparent in $\mathrm{Mr}$. Justice Jackson's opinions, becomes plain in a comparison of the Faulkner and Trager cases. Although the factual situation in the Faulkner case was squarely within the rule soon to be announced in $A \& P$, the conclusions reached were opposite. The patent in Faulkner was held valid even though the device was admittedly a combination of old elements, strikingly similar to the prior art. In Trager, on the other hand, the patent was held invalid despite the fact that it was remote to the prior art.

One product of this conflict is that the uniformity which had previously existed ${ }^{38}$ among the circuit courts on the question of invention had been shattered. Only the Courts of Appeals for the First Circuit 39 and for the District of Columbia 40 continue to hold simply that invention is an issue of fact. The Courts of Appeals. for the Second, 41 Fifth, 42 Sixth, ${ }^{43}$ Seventh, ${ }^{44}$ Ninth ${ }^{45}$ and Tenth 46 Circuits have all taken the position that invention is a question of law. The Courts of Appeals for the Fourth Circuit ${ }^{47}$ and for the Eighth Circuit 48 have adopted the view that invention is a factual issue but the standard of invention is a legal issue.

On its face, this last noted resolution of the Graver- $A \& P$ conflict, which Mr. Justice Jackson has articulated, is logically consistent. It implies that findings of invention, not clearly erroneous, may be set aside only if the trial court has applied the wrong test for invention. It implies also that there are

37 If this were the Court's intent, a full opinion rather than a per curiam reversal would seem to have been appropriate, in view of the fact that a large amount of judicial precedent was being overturned.

38 Hall Labs., Inc. v. Economics Lab. Co., Inc., 169 F.2d 65, 66-67 (8ih Cir. 1948); Harley C. Loney Co. v. Ravenscroft, 162 F.2d 703, 704 (7th Cir. 1947); Cusano v. Kotler, 159 F.2d 159, 160 (3d Cir. 1947); Schering Corp. v. Gilbert, 153 F.2d 428, 432 (2d Cir. 1946); Crowell v. Baker Oil Tools, Inc., 153 F.2d 972, 978 (9th Cir. 1946); O'Leary v. Liggett Drug Co., 150 F.2d 656, 666 (6th Cir. 1945); Bellavance v. Frank Morrow Co., 141 F.2d 378 (1st Cir. 1944); McElrath v. Industrial Rayon Corp., 123 F.2d 627, 629 (4th Cir. 1941).

39 Emerson v. National Cylinder Gas Co., 251 F.2d 152, 155 (1st Cir. 1958).

40 C. H. Boehringer Sohn v. Watson, 256 F.2d 713 (D.C. Cir. 1958).

41 Tatko Bros. Slate Co. v. Hannon, 270 F.2d 571, 572 (2d Cir. 1959).

42 Houston Oil Field Material Co. v. Claypool, 269 F.2d 134 (5th Cir. 1959).

43 National Latex Prods. Co. v. Sun Rubber Co., 274 F.2d 224, 238 (6th Cir. 1959).

44 Armour \& Co. v. Wilson \& Co., 274 F.2d 143 (7th Cir. 1960).

45 Bergman v. Aluminum Lock Shingle Corp. of America, 251 F.2d 801 (9th Cir. 1957).

${ }^{46}$ Blish, Mize \& Silliman Hardware Co. v. Time Saver Tools, Inc., 236 F.2d 913, 916 (10th Cir. 1956).

47 American Monorail Co. v. Parks-Cramer Co., 245 F.2d 739, 742 (4th Cir. 1957).

48 Steffan v. Weber Heating \& Sheet Metal Co., 237 F.2d 601, 602 (8th Cir. 1956). 
several such tests and that different ones are appropriate to different factual situations.

Although many such judicial tests have been devised, 49 there is some question whether any of these tests do more than indicate whether or not the subject matter of the patent was obvious to the "ordinary artisan," or, in other words, whether the legislative standard has been satisfied. What is common to all the case law discussion of these rules is a persistent reference to the "skilled mechanic." Also especially notable are the inevitable exceptions to the general rules.

It is usually held, for example, that there is no invention in a mere substitution of materials. ${ }^{50}$ In Hicks v. Kelsey, 51 where the patentee had substituted iron for a mixture of wood and iron, the Court said: "The use of one material instead of another in constructing a known machine is, in most cases, so obviously a matter of mere mechanical judgment, and not invention, that it can not be called an invention, unless some new and useful result . . . is clearly attained."52 Similarly, the Court held in Hotchkiss v. Greenwoods3 that the substitution of clay for wood or metal in doorknobs was not inventive. The Court there laid down the classic test for invention that "unless more ingenuity and skill ... were required . . . than were possessed by an ordinary mechanic acquainted with the business, there was an absence of that degree of skill and ingenuity which constitute essential elements of every invention." 54

But in United Shoe Mach. Corp. v. E. H. Ferree Co.,55 the court held that the substitution of aluminum for cast-iron in the arm of a machine used to manufacture shoes was an invention. In an illuminating discussion it stated:

But it is said that this was a mere substitution of material and therefore does not rise to the dignity of invention. To be sure substitution of material may not amount to patentable invention, but the facts of each case must determine whether or not it does. The use of one material instead of another in constructing a known machine is in most cases so obvious as a matter of mere mechanical judgment as not to be inventive thought, but it can amount to invention if some new and useful result or increase in efficiency and decided saving in the operation is clearly obtained. 56

It is also a general rule that the adaptation of a device to a new use is not an invention. 57 The meaning of this "rule" was stated in Potts v. Creager, 58

49 See Rivise \& Caesar, Patentabitity and Vaumity 146 (1930; 1 Walker, Patents 138-234 (3d ed. 1937).

so Florsheim v. Schilling, 137 U.S. 64, 77 (1890); Brown v. District of Columbia, 130 U.S. 87, 103 (1889).

5185 U.S. (18 Wall.) 670 (1873).

52 Id. at 673.

$54 \mathrm{Id}$. at 266.

5352 U.S. (11 How.) 248 (1850).

5564 F.2d 101 (2d Cir. 1933).

56 Id. at 103. (Emphasis added.)

57 Blake v. San Francisco, 113 U.S. 679, 682 (1885); Pennsylvania R.R. v. Locomotive Truck Co., 110 U.S. 490, 494 (1884).

s8 155 U.S. 597 (1895). 
where the Court said: "[nf a new use be so nearly analogous to the former one, that the applicability of the device to its new use would occur to a person of ordinary mechanical skill, it is only a case of double use, but if the relation between them be remote ... it may at least involve an exercise of the inventive faculty." 59

These examples can be multiplied.60 They illustrate that the judicial rules are largely sub-tests which indicate whether the patented device was the product of more than "ordinary skill."61 It is inevitable, therefore, that exceptions should be made when the facts of a case fit the category of the "rule," but the inventive quality of the subject seems especially great.62

The coexistence of a legislative test and judicial "subtests" takes on considerable significance in a case like $A \& P$, for there the district court found that the subject matter revealed more than "ordinary skill." The Supreme Court, on the other hand, applied, not the "skilled artisan" test, but the "combination-

59 Id. at 608.

60 It has been ruled that a mere change in size does not constitute invention because "the simplest mechanic can make such a modification." Planing-Machine Co. v. Keith, 101 U.S. 479, 490 (1879). But in Edison Elec. Light Co. v. United States Elec. Lighting Co., 52 Fed. 300 (2d Cir. 1892), the court held that a change in the diameter of a filament in Edison's electric light was inventive. Duplication of parts is usually not inventive. Slawson v. Grand Street R.R., 107 U.S. 649 (1882). But an exception has been made where the change "was more than mechanical." Goss Printing-Press Co. v. Scott, 108 Fed. 253, 260 (3d Cir. 1901). It is a "rule" that reversal of parts does not constitute invention (General Mach. Corp. v. Clearing Mach. Corp., 104 F.2d 553 (7th Cir. 1939)), but it has been pointed out that this is true only because reversal is usually obvious. "But the question whether it is obvious is to be determined by examination of the particular machine in which the change is made." Penfield v. Chambers Bros., 92 Fed. 630, 651 (6th Cir. 1899). And although changes in degree are usually not inventive (French v. Carter, 137 U.S. 239 (1890)), an increase in the degree of pitch of the Fourdrinier wire of a paper-making machine was an invention since what the patentee "saw and did was not obvious and did involve discovery and invention." Eibel Process Co. v. Minnesota \& Ontario Paper Co., 261 U.S. 45, 68 (1923).

${ }^{61}$ A survey of the cases cited by Walker and by Revise \& Caesar show that some courts, particularly in the more recent cases, apply the judicial rules without referring to the ordinary artisan test. See note 49 supra. One should observe also that the legislative requirement of non-obviousness is stated only negatively. See note 4 supra. Where courts do not apply the "ordinary artisan" test it is probably because the judicial rules have tended through frequent usage to assume a character of absoluteness. The legislative expression of this test is explained by the fact that courts have generally stated the requirement in negative terms, and the statute attempts to provide "a condition which exists in law and has existed for more than 100 years. ..." S. REP. No. 1979, 82d Cong., 2d Sess. (1952).

62 One is tempted to conclude that the existence of numerous exceptions renders the "rules" useless. It is possible, however, to reconcile the cases by adding to each rule a phrase which states the exception in very general terms. Thus a rule which is stated to apply only if tre subject matter does not produce "new and useful results" may be reconciled with wha:, in the absence of that phrase, would be exceptions to the rule. But this "new and usef $\lrcorner 1$ results" test appears to be merely a substitute for the "ordinary skill" test. If a result is not "new and useful," it is hardly likely to have required more than "ordinary skill"; and f more than "ordinary skill" is used, then the results are likely to be "new and useful." 
aggregation test." 63 Usually such a substitution of tests would have no effect on the outcome of the case. In $A \& P$, however, the substitution led to a reversal of the judgment. It appears to have done so, not because the two tests are inconsistent, but simply because the Supreme Court disagreed with the trial judge about the quality of the "invention." Doubtless the Supreme Court believed that the subject matter was obvious to a person of "ordinary skill." However, the Court could not reverse on this ground without overruling the Graver case. By relying instead on the rule for combination patents the Court was able to hold that the wrong standard had been applied.

This freedom to apply one of the sub-tests for invention where the trial judge has applied the "ordinary artisan" test means that a reviewing court can, in effect, broaden the normal scope of judicial review. If a finding under the latter test is a determination of fact, the Court in applying that test cannot reverse the judgment in the absence of clear error. But by ignoring the "skilled artisan" test and applying a sub-test not used by the lower courts, it can reverse a judgment, even without "exceptional showing of error," on the grounds that the wrong standard was applied. Such an analysis indicates, not only the inadequacy of the rule being applied in the Fourth and Eighth Circuits, but also shows how the $A \& P$ Court was able to deviate so sharply from the earlier cases without overruling any of them.

63 The rationale of this "rule" is somewhat elusive. It has been stated that "it is practically impossible to claim invention of an article which is made up of known old elements." Gerhardt v. Kinnaird, 162 F. Supp. 858, 862 (E.D. Ky. 1958). But it is well established that a combination may be patentable if its results are the product of a union of the separate parts. Hartman Furniture Co. v. Banning, 59 F.2d 129, 131 (7th Cir. 1932). The "rule" has developed that a combination is inventive if it "performs some new or different function." Photochart v. Photo Patrol, Inc., 189 F.2d 625, 627-28 (9th Cir. 1951); or if it "produce[s] a new and useful result." Weller Mfg. Co. v. Wen Prods., Inc., 231 F.2d 795, 798 (7th Cir. 1956). However, this "rule" is inadequate since a new and useful result "does not necessarily make the device patentable," Cumo Eng'r Corp. v. Automatic Devices Corp., 314 U.S. 84, 90 (1941), and a combination may be patentable even if its function is old. Derre \& Co. v. Rock Island Plow C0., 84 Fed. 171, 176 (7th Cir. 1898). Consequently the conclusion seems justified that "the controlling question is whether... the new and useful results were obtained in a manner which was ... not obvious to persons of ordinary skill in the art." Cold Metal Process Co. v. Republic Steel Corp., 233 F.2d 828, 836 (6th Cir. 1956).

One might argue that it is a well settled rule that aggregations are never patentable. See 1 WALKer, PATENTS $\$ 42$ (3d ed. 1937, Supp. 1960). It is believed, however, that this rule is valid only insofar as aggregations are "obvious." The Supreme Court indicated as much in Thatcher Heating Co. v. Burtis, 121 U.S. 286, 294-95 (1887), where it held that the device in suit was an aggregation: "If, however, to adapt these separate elements to each other ... required the use of means not within the range of mere mechanical skill, then it would be true that the invention of such means ... would be patentable. ... Nothing of that, however, appears in this case." This view is also supported in Sachs v. Hartford Elec. Supply Co., 47 F.2d 743, 748 (2d Cir. 1931), where the court, speaking through Judge L. Hand, said: "[W]e can find little advantage in a discussion of what is or what is not an "aggregation'.... [I]nventions depend upon whether more was required to fill the need than the routine ingenuity of the ordinary craftsman. . . . Any attempt to define [the standard] . . . in general terms has always proved illusory; it is best to abandon it." 
Since the approach of the $A \& P$ case to the problem of invention provides neither consistent doctrine nor logical satisfaction, a different type of analysis should be considered. It should be noted first that the question whether a device was obvious to a "person having ordinary skill in the art" is neither legal nor factual in the usual sense in which those terms are used.64 The term "fact" generally connotes "something which has happened or existed," 65 while the term "law" means essentially "a body of principles and rules which are capable of being predicated in advance." 66 The essence of invention, on the other hand, is that it involves the application of a highly ambiguous legislative standard to a particular set of facts. 67 The classification of invention as a legal, factual or mixed question for a purpose of determining the scope of appellate review is not to be determined syllogistically by proceeding from the meaning of "law" and "fact" 68 as a major premise and statements of the findings below"

64 Cf. Lutz, Question of Fact and Questions of Law in Patent Litigation, 38 J. PAT. OFF. Soc'y 600 (1956), where the writer suggests that the tendency to regard patentability as an issue of fact is a resuit of the early practice in patent law of trying cases before a jury. For other discussions of this problem, see Deller, The Problem of Invention in the Law of Patents, 28 J. Pat. OfF. Soc'y 797 (1946); Kirschstein, The Two-Court Rule, 34 J. Pat. OfF. Soc'y 365 (1952); Note, Patentable Invention as a Question of Law, 43 ILL. L. REv. 535 (1948).

65 Bohlen, Mixed Question of Law and Fact, 72 U. PA. L. REv. 111, 112 (1924).

66 Ibid.

${ }^{67}$ It is the ambiguity that distinguishes this type of question from other situations in which a legal standard is applied to the facts as found. It is perhaps true that "all questions of fact for a jury or for a court ... must be decided with reference to all relevant rules of law. ..." Thayer, A Prelnminary Treatise on Evidence at the Common Law 224-25 (1898). But where the standard or "relevant rule" is clear, the question is properly termed "factual," since the conclusion of the judge or jury will always follow inevitably from findings of fact. If, for example, a statute provided that persons weighing less than 150 pounds would be entitled to receive food packages from the federal government, it would be a question of fact whether a given individual should receive them. If instead the same privilege were accorded to "needy," "intelligent," or "careful" people, the question would be similar to the problem of invention because the judge or jury would have to determine what the legislative term meant before they could apply it.

Similarly, it appears that novelty involves the application of a somewhat uncertain legislative standard, and the cases usually hold that novelty is a question of fact. See cases cited note 7 supra. This would be true if novelty presented only a question of whether two devices were identical, but the Graver case held that equivalence "does not require complete identity for every purpose and in every respect." 339 U.S. 605, 609 (1950). It is believed nonetheless that "equivalence" is a term sufficiently clear to permit a judge or jury to reach a verdict without a significant amount of "interstitial legislation."

On the other hand, it has been said of invention that "the word cannot be defined in such manner as to afford any substantial aid in determining whether the particular device involves ... that impalpable something which distinguishes invention from simple mechanical skill." McClain v. Ortmayer, 141 U.S. 419, 427 (1891). The extreme ambiguity of this standard justifies different treatment.

${ }^{68}$ See generally Bohlen, Mixed Questions of Law and Fact, 72 U. PA. L. REv. 111 (1924); Brown, Fact and Law in Judicial Review, 56 HaRv. L. Rev. 899 (1943); Green, Mixed Questions of Law and Fact, 15 HARv. L. REv. 271 (1901); Mortis, Law and Fact, 55 HARV. L. REv. 1303 (1942); Paul, Dobson v. Commissioner: The Strange Ways of Law and Fact, 57 HARY. L. Rev. 753 (1944); Stern, Review of Findings of Administrators, Judges and Juries: A Comparative Analysis, 58 HARV. L. REv. 70 (1944). 
as a minor premise, to a conclusion that appellate courts may or may not review. 69 Rather, it is submitted, a solution may be more fruitfully found by pursuing a consideration of the purpose of Rule 52(a).

Basically that rule represents a recognition that trial courts are better able to make sound determinations of fact than appellate courts insofar as the trial judge's determination rests on the advantage of seeing and hearing the witnesses. Where this advantage is lacking, however, courts of appeals have reviewed much more freely. Until it became common for equity courts to hear oral evidence, the facts found by these courts, as well as the legal conclusions they reached, were reviewed on appeal.70 And it is still a general rule that when all the evidence is documentary, an appellate court, because it is in as good a position to evaluate the evidence as the trial judge, may disregard findings of fact.71 The real question thus is whether a trial court is better able than an appellate court to determine the presence or absence of invention. ${ }^{72}$ On the assumption that the latter is equally able, there would seem to be no reason for a court of appeals to decline to review a determination of invention. ${ }^{73} \mathrm{~A}$ trial judge is likely to be neither more able nor more expert than an

69 Indeed, the problem is perhaps insoluble as a matter of definition. One writer has said that "what is law to one Justice is fact to another, and perhaps vice versa when the next case comes along. ... Congenial assumptions are frequently rushed in as synthetic substitutes for analysis, and 'fact' and 'law' fly thick and fast. Verbal ingenuity easily fits the desired result." Paul, Dobson v. Commissioner: The Strange Ways of Law and Fact, 57 HARv. L. REv. 753, 812 (1944).

70 See note 16 supra.

71 Seagrave Corp. v. Mount, 212 F.2d 389, 394 (6th Cir. 1954); Equitable Life Assur. Soc'y v. Irelan, 123 F.2d 462, 464 (9th Cir. 1941). It has also been held that where all facts are stipulated an appellate court may substitute the inferences it draws from these facts for those drawn by the trial judge. Wiggington v. Order of United Commercial Travelers of America, 126 F.2d 659, 661 (7th Cir. 1942); Tipton v. Bearl Sprott Co., 93 F. Supp. 496, 498 (S.D. Calif. 1950). These rules are followed also in patent cases. In United States v. Esnault-Pelterie, 303 U.S. 26, 30 (1938), for example, the Court said: "[W] here . . it appears that no substantial dispute of fact is presented, and that the case may be determined by a mere comparison of structures and extrinsic evidence is not needed ... the questions of invention and infringement may be determined as questions of law." Accord, Singer Mfg. Co. v. Cramer, 192 U.S. 265, 275 (1904); Heald v. Rice, 104 U.S. 737, 749 (1881). See generally Judge Frank's opinion in Orvis v. Higgins, 180 F.2d 537, 539-40 (2d Cir. 1950).

72 It has been pointed out that under Rule 52(a) the opinion of the appellate court rather than that of the trial judge "is to prevail, except only insofar as a 'due regard' for the opportunity of the trial court to judge of 'credibility,' and a proper respect for the trial court's opinion, should stay its hand." Steffen, The Prima Facie Case In Non-Jury Trials, 27 U. CHI. L. REV. 94, 121 (1959). The author there argues that Rule 52(a) was intended to broaden the scope of judicial review since prior to its adoption a judgment in an action at law could be set aside only in the absence of "substantial evidence." The new rule requires reversal even where "substantial evidence" exists provided there is "clear error." Therefore the rule is said to have been "carefully chosen to give the appellate courts power in law cases to take greater responsibility than theretofore." Id. at 124.

73 The findings of evidentiary facts generally must be accepted by the appellate court. If, for example, the question was whether a motor carrier made "frequent and regular" trips of more than 500 miles, the findings of the trial court as to how many trips had been made 
appellate judge in this respect. He is, therefore, in no better position to decide whether a given set of facts falls within the legislative standard.74

It has sometimes been argued, however, that the function of appellate courts is to interpret rather than to apply legislative standards and that ultimate facts should, therefore, be reviewed only if it will be possible to construct a general rule applicable to future litigation. ${ }^{75}$ One need not labor the point that interpretation and application are often virtually indistinguishable. Every application is to some extent an interpretation. 76 This is not to deny that there is a significant difference between these functions, but the difference is one of degree, not one of kind. Consequently, if it is the province of appellate courts to give content to legislative language, it is difficult to understand why they should not so do in the most convenient way possible. An ambiguous standard like the "ordinary artisan" cannot be clarified by general principles since the factual situation upon which those principles would depend is not likely to recur. If appellate courts are to perform their function of clarifying legislative terms at all, they must do so in such cases through application of the standard. 77 The cardinal point therefore is that invention is largely a question of policy, ${ }^{78}$ and if it is to be decided by the courts at all, as it must under the

and over what period of time these trips occurred would be binding on the appellate court. Whether the trips made during the period stated were sufficient to constitute "frequent and regular" trips is a very different issue, and the desirability of permitting appellate courts freely to substitute their judgment for that of the trial court on such an issue is the question which this discussion attempts to answer.

74 Professor Steffen argues that appellate courts are actually in a better position "to pass on the law and facts of a case" since "the appellate bench is relieved of the hurry of daily trial work; there is the benefit of consultation; and, more important, the case may be seen in fuller perspective. ..." Steffen, supra note 72, at 123.

75 Phelps, What Is $A$ "Question of Law," 18 U. CINC. L. ReV. 259, 273 (1949). "We do not sit in judgment on the decisions of the lower federal courts because we are endowed with some special measure of discernment, but because it is imperative that on matters of general concern, that is on matters of principle, there should be one authoritative and unifying expositer of federal law." Aro Mfg. Co., Inc. v. Convertible Top Replacement Co., 365 U.S. 336,379 (1961) (dissenting opinion). This rationale however was expressly confined to review oy the Supreme Court and is not applicable to appeals to circuit courts.

76 "Each application is a further refinement of principle, even if it is a refinement which may not be useful in the future." Paul, supra note 69 , at 828 .

77 It may appear that this argument presupposes that appellate judges are better qualified than trial judges. Suffice it to say that if that assumption is implicit in this discussion, it is indulged to no greater extent than it is when one agrees that appellate courts should review questions of law. The main point is that the court which is better qualified to define legislative terms is necessarily better qualified to determine whether those terms are embraced by a particular set of facts. To permit an appellate court to substitute its judgment for that of the trial judge in the one case, while requiring it to defer to his judgment in the other case seems inconsistent.

78 Policy considerations are of paramount importance in the patent field. It has been asserted that patents stimulate invention and investment and are therefore the basis for economic progress. Stedman, Invention and Public Policy, 12 LAW \& CoNTEMP. Prob. 649, 
general standard of the Patent Act, the opinion of a trial judge should not be final.79

Furthermore the argument that appellate courts should limit review to cases calling for interpretation assumes that the sole function of these courts is to give guidance to trial judges. But a court of appeals also has a duty to assure, by correcting errors made below, that all litigants are given just and equal treatment. 80 The courts themselves recognize this duty whenever they reverse a judgment because of clearly erroneous findings of fact.81 If it were the sole function of appellate courts to enunciate broad principles, none of these cases would be reviewed.

The foregoing discussion indicates that the scope of appellate review should be just as broad as if invention were a question of law. It is nonetheless important to a clear understanding of the issues of patentability that invention be

653 (1947). See generally discussion by Judge Frank in Picard v. United Aircraft Corp., 128 F.2d 632, 638-45 (2d Cir. 1942) (concurring). Contrariwise, it is argued that invention may be induced by "competition, the instinct of contrivance, the desire to enhance one's reputation and intellectual inquisitiveness." Note, The Supreme Court and the "Standard of Invention," 49 Colum. L. REv. 685, 692 n.48 (1949). It has been suggested that the Patent Office, because it favors the publication of all useful discoveries and the maintenance of a public record which will facilitate the evaluation of future "inventions," may be expected to be liberal in its grants. See Comment, Patent Policy and Invention, 46 InL. L. REv. 609, 613 n.18 (1951). Appellate courts on the other hand have tended, where they review at all, to restrict patentability in the interest of thwarting "limited monopoly." See Brown, Developments in the Patent Law as Effected by Adjudications, 22 J. PAT. OfF. Soc'Y 587 (1940); Dodds \& Crotty, The New Doctrinal Trend, 30 J. Pat. OfF. Soc'y 83 (1948); Evans, Disposition of Patent Cases by the Courts, 24 J. PAT. OFF. Soc'y 19 (1942); Smith, Recent Developments in Patent Law, 44 Mich. L. REv. 899 (1946). And it has been ruled that patents may also be limited by construing the scope of the patent narrowly. Monsanto Chemical Co. v. Coe, 145 F.2d 18 (D.C. Cir. 1944). But since the high cost of defending a patent suit may make infringement even of invalid patents impracticable, these measures may not succeed in limiting the effect of patent monopoly. Picard v. United Aircraft Corp., 128 F.2d 632, 641-42 (2d Cir. 1942) (concurring opinion).

79 The view expressed here that appellate courts should review applications of highly ambiguous legislative standards is supported by the concurring opinion of Mr. Justice Brennan in Aro Mfg. Co., Inc. v. Convertible Top Replacement Co., Inc., 365 US 336, 362 (1961). The issue there was whether the manufacture of an unpatented part of a patented combination constituted an infringement. The general rule is that "the purchaser of a patented article has a right to repair it. ... [B]ut it is not permissible . . . to reconstruct [it]. ..." 3 WALKER, PATENTS 1771 (Deller's ed. 1937). Mr. Justice Brennan wrote: "I disagree with my Brother Harlan that we should refrain from making an independent application of the proper standard in this case because of the conclusion of both lower court that the replacement... . [of the constituent part of the combination] constituted 'reconstruction.' I would suppose that 'repair' or 'reconstruction' is so far a question of law as to relieve appellate review from the restraints of . . . [Rule] 52(a)." 365 U.S. at 367. (Emphasis added.) The position there expressed is that the issue in the case is so much a matter of law that review should not be precluded by Rule 52(a).

803 Moore, Federal Practice 3118 (ist ed. 1938).

81 Such a reversal has occurred in patent cases even where the validity of the patent had been determined by a jury. See Packwood v. Briggs \& Stratton Corp., 195 F.2d 803 (3d Cir. 1952). 
recognized as a problem of applying a general legislative standard, rather than be veiled as an issue of law. The term "questions of law" has acquired connotations that are inconsistent with the nature of the problem of invention.82 To employ this term is likely to increase the confusion presently existing in this field. More significantly, the courts which now hold that invention is a question of law do so on the authority of the $A \& P$ case. As indicated in this comment, however, $A \& P$ does not support that proposition. ${ }^{83}$ Therefore, to consider invention an issue of law may not only be confusing in view of the sense in which that term is usually used, but may also lead one to believe that the policy of review is dependent upon the soundness of the $A \& P$ decision.

Several courts have already tended toward the position that a trial judge's application of ambiguous standards may be fully reviewed.84 For example, the difference between the degree of conclusiveness of findings of evidentiary fact and that of inferences drawn from those facts was sharply illustrated in the court's discussion in Kuhn v. Princess Lida of Thurn \& Taxis. 85 After indicating that evidentiary findings are binding, the court said: "Rule 52(a) does not operate, however, to entrench with like finality the inferences or conclusions drawn by the trial court from its fact findings. And so, while accepting the facts competently found by the trial court as correct, an appellate court

82 Compare note 67 supra with text accompanying note 66 supra.

83 The $A \& P$ case did not say that invention is a question of law but rather that the standard of invention is a matter of law. This distinction is important unless one takes the position that the test for invention includes the precise meaning of its verbal formulation. Under the latter view any disagreement as to the existence of an invention would necessarily be the result of a disagreement as to the standard for invention regardless of the formula of words used, provided there was a common acceptance of the evidentiary facts. That .he $A \& P$ Court did not adopt this view is clear from the fact that when it reversed the "ower court's determination that there was an invention it did so, not on the grounds that the wrong standard had been applied, but apparently on the grounds of "clear error." The Court employed the argument that the wrong standard had been applied only where it believed that no finding of fact as to invention had been made. Furthermore, the rationale of the $A \& P$ case is quite weak because of the Court's substitution of tests. Therefore, the case may be unable to withstand future judicial scrutiny.

84 Cf. Baumgartner v. United States, 322 U.S. 665, 670-71 (1944), where Mr. Justice Frankfurter said: "The conclusiveness of a 'finding of fact' depends on the nature of the materials on which the finding is based. . . . Finding so-called ultimate 'facts' more clearly implies the application of standards of law. And so the 'finding of fact' even if made by two courts may go beyond the determination that should not be set aside here." It is nevertheless true that the law is unsettled as to whether appellate courts may substitute their judgment for that of the trial court in the application of a vague standard. For example, it has been ruled that an appellate court may not review a trial judge's determination of negligence. Des Isles v. Evans, 255 F.2d 235 (5th Cir. 1955). Contra, Barbarino v. Stanhope S.S. Co., 151 F.2d 553, 555 (2d Cir. 1945), where Judge Learned Hand stated: "In the end no decision can be reached except by choosing between two human interests, one of which must be sacrificed. Such choices are the very stuff of law, and as to them appellate courts have no reason to defer to the decisions of courts of first instance."

85119 F.2d 704 (3d Cir. 1941). 
remains free to draw the ultimate inferences and conclusions which, in its opinion, the findings reasonably induce." 86

There appears to be a trend away from the early rule that invention is a question of fact. To the extent that the new rule permits full review of lower court determinations of invention, the change is a salutary one. The courts, however, have not yet succeeded in working out a suitable rationale to support their policy of review.87 It is suggested that such a rationale may be found in the desirability of permitting appellate courts to give content to legislative standards that are exceptionally general.

86 Id. at 705-06.

87 In recent years appellate courts have attempted to state a rationale which would support a policy of review. Perhaps the most satisfactory of these opinions is Armour \& Co. v. Wilson \& Co., 274 F.2d 143 (7th Cir. 1960), where after reviewing previous cases the court said: "The question of what constitutes patentable invention may be broken down "into its component parts: what the prior art was and what the patentee did to improve upon it, and then, whether what the patentee did is properly to be classified as an invention. ..." The court argued that the first two questions are issues of fact but that the final step of deternining whether what was done merits a patent "requires the application of the correct lega! criteria to the factual determination made by the trial court," and is therefore a question of law. Although the court's emphasis upon the $A \& P$ case seems misplaced and its use of the label "question of law" may lead to confusion, the effect of that opinion is quite similar to the solution suggested in this comment. Both methods would permit the trial cou.t to make findings of evidentiary facts but would allow full appellate review of the application of the legislative standard to the facts as found. 